\title{
Determinant Factors of Financial Management Behavior Among People in Jakarta During COVID-19 Pandemic
}

\author{
Mieske Anggraini Halim ${ }^{1}$ Ignatius Roni Setyawan ${ }^{1 *}$ \\ ${ }^{1}$ Department of Management, Faculty of Economics \& Business, Universitas Tarumanagara, Jakarta 11470, Indonesia \\ "Corresponding author.Email: ign.s@fe.untar.ac.id
}

\begin{abstract}
The purpose of this research is to analyze the influence of Financial Knowledge, Financial Attitudes, and Financial Literacy on Financial Management Behavior for the people in Jakarta during COVID-19 pandemic.. During the pandemic, many business activities have been exposed to tight restriction by the government, hence the purchasing power of people will be decreased. To examine the alternative hypothesis, this research uses the Structural Equation Modeling (SEM) with the Smart PLS. The research sample was collected by using an online Google Form Questionnaire with a purposive non-probability sampling type with a total of 185 respondents. The result of this research indicates that Financial Knowledge, Financial Attitudes, and mainly Financial Literacy have significant influences on Financial Management Behavior. Therefore, it can be concluded that the financial management behavior based on Theory of Planned Behavior (TPB) by Ajzen \& Fishbein remains consistent during COVID-19 pandemic. This research has contributed that in the COVID-19 pandemic, the purchasing power of people will not decrease evidently. Overall, this research suggests that every person should behave financially well and wise in managing their finances, investment, and business activities. With the increase of financial literacy of people during COVID-19 pandemic as Deficit Spending Units (DSUs), then its counterpart in Financial System i.e. Surplus Income Units (SIUs) will also work effectively.
\end{abstract}

Keywords: Financial Knowledge, Attitude and Literacy, Financial Management Behavior, COVID-19 Pandemic, People in Jakarta

\section{INTRODUCTION}

In this recent era of disruption, people must have insight and knowledge in managing their finances and incomes. The ability to manage finances and make the right decisions at this time is a real challenge that must be faced by every person in everyday life. Therefore, people are often faced with a situation where they have to sacrifice one of their interests for the sake of another. Initially, people consumed only to fulfill their primary needs. However, as technological and economic advances develop in a country, people are competing to meet their secondary and tertiary needs, such as the absence of emergency planning, allocation of funds for the future, minimal savings, or investment activities. This can be seen from the increasing needs of people and a high lifestyle that makes a lot of people unaware that they are using their money without properly calculating their expenses beforehand.

Knowledge of finance is so important at this time, seeing the condition of people who tend to buy goods or spend money for something they want, not what they need. In addition, financial attitudes can also affect financial management behavior. Thus, it can be inferred that when people feel calm about their personal finances, it can be seen evidently from their responses, statements, or opinions as a reference for the attitude of the people itself.

Planning, management, and control are activities of financial management. In finance, these activities are important to achieve financial well-being. According to the people, the difficulties they experience in managing their personal finances are caused by increasing consumptive behavior. This conservative behavior itself encourages people to use and consume goods or services excessively without thinking about their priorities.

The Financial Services Authority (OJK) conducted the National Financial Literacy Survey (SNLIK) which was conducted on November 7, 2019 \{see [14]\}. This research is to determine the level of financial literacy of the people. Last year, the financial literacy index reached $38.03 \%$ and the financial inclusion index was $76.19 \%$. This is considered a good result compared to the results of SNLIK 2016, when the financial literacy index is $29.7 \%$ and the financial inclusion index is $67.8 \%$. [14]. By the end of 2019, the world was struck by a new virus called COVID-19. The COVID-19 Pandemic has made many countries helpless and caused critical problems, such as the current world economy. Since the first case of COVID-19 in Indonesia 
occurred, the government has urged the public to carry out activities from home. This is done to reduce the risk of transmission of the COVID-19 virus. As a result, economic activity is disrupted because most people are now at home. This situation will eventually have a potential to cause a global crisis. The large number of people affected by layoffs has caused people's income to decline and even obtain no income at all. A reduction in income also affects financial decisions. COVID-19 pandemic indirectly has a considerable influence on financial decisions. This study tries to analyze the influence of Financial Knowledge, Financial Attitudes, and Financial Literacy on Financial Management Behavior of the people in Jakarta during Covid-19 pandemic. This research aims to explore how far the determinant of financial management behavior based on Theory of Planned Behavior (TPB) by [1] will remain consistent in the COVID-19 pandemic.

During this pandemic, many business activities has been exposed to tight restriction from government, hence the purchasing power of people will decrease. This research will examine the alternate hypothesis by using the Structural Equation Modeling (SEM) with Smart PLS as utilized by many other studies in financial management behavior and alike. To be more specific, this research will identify whether the financial behavior will change due to the COVID-19 pandemic which will be a further exploration of the literature study previously conducted by [18].

\section{LITERATURE REVIEW AND HYPOTHESES DEVELOPMENT}

\subsection{Literature Review}

\subsubsection{Theory of Planned Behavior (TPB)}

The theory used in this research is Theory of Planned Behavior (TPB). According to [1], Theory of Planned Behavior (TPB) is a suitable theory to explain any behavior that requires planning and explain that a person's behavior occurs due to the intention to carry out a behavior in everyday life. Theory of Planned Behavior (TPB) is an expansion theory of the Theory of Reasoned Action (TRA) which explains the two main factors that form a person's intention towards behavior, namely: attitude and subjective norms.

Attitude is a factor that exists within a person which is used to provide a response, both in positive and negative terms to provide an assessment of a matter. Subjective Norm is a social pressure felt by someone to do or not to do something. People will conduct a behavior if there is encouragement or motivation from others [6]. Theory of Planned Behavior (TPB) has 2 additional features compared to Theory of Reasoned Action (TRA). This first feature is a theory that assumes that perceived behavioral control has motivational implications for new interests being connected to behavior. The second feature is the direct relationship between perceived behavioral control and behavior. Thus, perceived behavioral control can directly influence behavior.

\subsubsection{Financial Knowledge \& Financial Skill}

Financial knowledge is an understanding of financial concepts that are needed and used in everyday life. A society with better financial knowledge has better financial management behavior for himself and his family to improve the economy and financial prosperity in the future. To obtain financial knowledge, it is necessary to develop financial skills and learn to use financial tools. Financial skill is related to the how people use many source of fund and allocate to many essential project. This skill will depend on the extent to which this person understands the exact source of funds and the accuracy of the project as well.

\subsubsection{Financial Attitude}

Financial attitude is a state of opinion, judgment, and also thoughts about finance. A good financial attitude can change the way things appear based on a person's moral, cultural, and personal values towards financial decisions and products. According to [13], financial attitudes can determine how an individual spends, saves, collects, and spends money. Indirectly, the financial attitude that an individual has can help that individual in determining their behavior in terms of personal financial budgeting, such as managing finances or how to determine individual decisions about the type of investment to be taken [12], [9] \& [13],

\subsubsection{Financial Literacy}

Financial Literacy is knowledge, beliefs, and skills that influence the attitudes and behavior of a society to improve financial management and decision making with the aim of achieving prosperity. According to study of [20], financial literacy occurs when a person has a set of skills and abilities that enable a person to utilize existing resources to achieve expected goals.

\subsection{Hypothesis Development}

\subsubsection{Financial Knowledge and Financial Management Behavior}

Financial knowledge is an understanding of financial concepts that are needed and used in everyday life. A society with better financial knowledge has better financial management behavior for itself and its families to improve the economy and financial welfare in the future. To obtain financial knowledge, it is necessary to develop financial skills and learn to use financial tools. The relationship between financial knowledge and financial management behavior can be stated as follows, if someone has adequate financial knowledge, it is expected to produce good financial management behavior. This means that this person is able to make good financial management decisions and 
can behave wisely when his financial condition has a surplus and a deficit. When there is a surplus, remember to set aside funds for unexpected needs. And when the deficit is still able to carry out financial activities well. Studies conducted by [10], [9] \& [12\} found the influence of financial knowledge on financial management behavior.

\subsubsection{Financial Attitude and Financial Management Behavior}

Financial attitude is a state of opinion, judgment and also thoughts about finance. A good financial attitude can change the way things appear based on a person's moral, cultural, and personal values towards financial decisions and products. According to [13], financial attitudes can determine how an individual spends, saves, collects, and spends money. Indirectly, the financial attitude that an individual has can help that individual in determining their behavior in terms of personal financial budgeting, such as managing finances or how to determine individual decisions about the form of investment to be taken. According to [12], [9] \& [13] financial attitude has an influence on financial management behavior.

\subsubsection{Financial Literacy and Financial Management Behavior}

Financial Literacy is the knowledge, beliefs, and skills that influence the attitudes and behavior of a society to improve financial management and decision making with the aim of achieving prosperity. According to [20], financial literacy occurs when a person has a set of skills and abilities that enable a person to use existing resources to achieve expected goals.

According to [20, [21], [3], [16\}[, [15] \& [2] we can state that financial literacy will have a strong influence on the need for financial management. This is because strong financial literacy is built from the financial knowledge and attitude of an individual that has been formed for a long time. In this way, individuals will be able to make good financial decisions when surplus and deficit conditions are experienced. Accessibility to creditors and investors will always be maintained.

Overall the relationship between variables and the above framework at Figure 1 below:

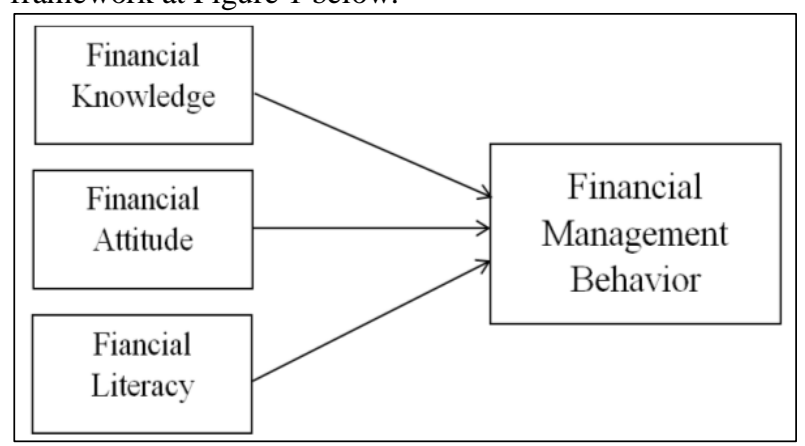

Figure 1 Theoretical Framework
Based on Figure 1 above, then the alternative hypothesis can be formulated as follows:

$\mathrm{H}_{1}$ : Financial Knowledge affects Financial Management Behavior of people in Jakarta during COVID-19 pandemic

$\mathrm{H}_{2}$ : Financial Attitude affects Financial Management Behavior of people in Jakarta during COVID-19 pandemic

$\mathrm{H}_{3}$ : Financial Literacy affects Financial Management Behavior of people in Jakarta during COVID-19 pandemic

\section{RESEARCH METHOD}

\subsection{Design}

The research design used in this research is descriptive with the aim of obtaining data that describes an interesting topic. The data collection used is cross-sectional studies where data collection was done only once during a certain period. The sampling technique used in this research is nonprobability sampling where not all individuals have the same opportunity to be selected as samples

\subsection{Data Collection}

Data collection was carried out by distributing questionnaires presented in Google Form which contained questions for each variable which were distributed to respondents (people in Jakarta) by using Line, WhatsApp, Instagram, etc. This research consists of Financial knowledge, Financial Attitude, and Financial Literacy as the independent variables and Financial Management Behavior as the dependent variables. The measurement scale used to value the answers is the Likert scale from 1 to 5 with 1 indicating "strongly disagree" and 5 indicating "strongly agree".

\subsection{Data Analysis Method}

This study uses the PLS-SEM method using Smart PLS v.3.2.8 software. The population in this study was people affected by COVID-19 in Jakarta with a sample of 185 respondents. In this test, there is an outer model test and an inner model test. In the outer model analysis test, there is a validity test and a reliability test. In this study the results of the validity convergent analysis can be declared to meet the criteria if the AVE value is greater than 0.50 (AVE > 0.50) and the loading factor value is greater than 0.50 (loading factor $>0.5$ ) [5]. Then for discriminant validity analysis, it shows that the cross loading value is said to meet the criteria if the value of each indicator for each variable has a value that is greater than the value of other cross loading [7]. Meanwhile, the reliability analysis uses Cronbach's alpha and Composite Reliability values. If Cronbach's alpha coefficient $>0.7$, then the question is declared reliable [8]. 
If the Composite Reliability coefficient is $>0.6$, the question is declared fulfilled [7].

In testing the inner model (structural model) it includes testing of coefficient of determination $\left(\mathrm{R}^{2}\right)$, predictive relevance $\left(\mathrm{Q}^{2}\right)$; path coefficients; and effect sizes $\left(\mathrm{f}^{2}\right)$ [8]. According to [7], there are 3 values of the coefficient of determination used as a very rough guide, $\mathrm{R}^{2}$ values are 0.25 (weak), 0.50 (moderate), and 0.75 (substantial). If the value of $\mathrm{Q}^{2}$ is greater than 0 , the exogenous variable is said to be able to predict the endogenous variable accordingly and well [7].

\section{RESULTS AND DISCUSSION}

Based on the results of the data collected, it can be seen that as many as 86 people $(46.5 \%)$ are male and the remaining 99 people $(53.5 \%)$ are women. As many as 133 people $(61.1 \%)$ are $21-25$ years old, 32 people $(17.3 \%)$ are $26-30$ years old, 2 people $(14.6 \%)$ are over 30 years old, and the rest are 13 people ( $7 \%$ ) under 20 years old. The monthly income obtained by respondents is as many as 69 people (37.3\%) have an income ranging from IDR 2,000,001 $4,000,000$, as many as 63 people $(34.1 \%)$ have an income above IDR $6,000,001$, as many as 38 people $(20.5 \%)$ have an income range of IDR 4,000,001 - 6,000,000, and the remaining 15 people $(8.1 \%)$ have income below IDR $2,000,000$.

The impact of COVID-19 experienced by the people is divided into 4 parts, namely: economy, online shopping, food delivery, and work from home. From the impacts experienced by the people, almost all people have experienced these impacts. From the data collected, 157 people $(84.9 \%)$ experience the impact in the economic sector, 96 people $(51.9 \%)$ experience the impact in the online shopping sector, 75 people $(40.5 \%)$ experience the impact in the field of food delivery, and as many as 141 people $(76.2 \%)$ experience the impact in the field of work from home.

According to [8] the value of the path coefficients in the structural model is evaluated from the magnitude, sign side, and significance. The value of the Path coefficient is -1 to +1 . Where the - (negative) sign in this analysis indicates that there is a negative relationship to the variables in the study while the + (positive) sign indicates a positive relationship to the variables in the study. Effect Sizes are categorized into 3 categories, namely a value of 0.02 indicating a weak effect, a value of 0.15 indicating a moderate effect, and a value of 0.35 indicating a strong effect (Henseler et al., 2009). Then the results of the GoF calculation are divided into three, namely low small $(\mathrm{GoF}=0.1)$, medium $(\mathrm{GoF}=$ $0.25)$, and large $(\mathrm{GoF}=0.36)$. The determination of the GoF criteria uses the calculated values obtained by the formula above [19]. Then a research hypothesis can be accepted or not rejected if the t-statistic value is greater than $1.96(\mathrm{t}-$ statistic > 1.96) [7]. In summary in figure 2, the results of the empirical model are as follows:

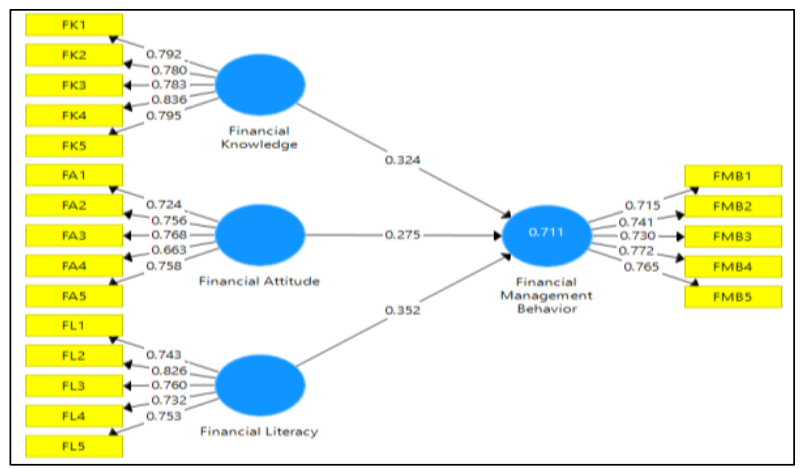

Figure 2 Result of Empirical Model by SMART PLS 3.28

Table 1 Hypothesis Testing Result

\begin{tabular}{|c|c|c|}
\hline Variables & $\begin{array}{c}\text { Patch } \\
\text { Coefficient }\end{array}$ & T-Stat \\
\hline $\begin{array}{c}\text { Financial } \\
\text { Knowledge }\end{array}$ & 0.324 & $5.739 * * *$ \\
\hline $\begin{array}{c}\text { Financial } \\
\text { Attitude }\end{array}$ & 0.275 & $4.237 * * *$ \\
\hline $\begin{array}{l}\text { Financial } \\
\text { Literacy }\end{array}$ & $\mathbf{0 . 3 5 2}$ & $\mathbf{5 . 5 8 9} * * *$ \\
\hline $\begin{array}{l}\text { Notes: } \\
* * * \text { : significant at 1\% level } \\
* *: \text { significant at 5\% level } \\
*: \text { significant at } 10 \% \text { level }\end{array}$ \\
\hline
\end{tabular}

Based on the results of testing financial knowledge of financial management behavior at at Table 1, it has a statistical t-value of 5.739 (t-statistics > 1.96) and a p-value of 0,000 ( $\mathrm{p}<0.05$ ), so that $\mathrm{H} 1$ can be accepted (not rejected), with the conclusion that there is a significant and positive influence between Financial Knowledge on Financial Management Behavior. The result is consistent with revious research from: [10], [4], [17], and [13] which state that financial management behavior has been affected by financial knowledge.

Based on the results of the Financial Attitude test on financial management behavior, it has a t-statistical value of 4.237 (t-statistics > 1.96) and a p-value of $0.000(\mathrm{p}<0.05)$, so that $\mathrm{H} 2$ can be accepted (not rejected), with the conclusion that there is a significant and positive influence between Financial Attitude on Financial Management Behavior. The results are supported [12], [9], [11], [13], and [21] which state financial management behavior has been influenced by financial attitude.

Based on the results of the Financial Literacy test on financial management behavior, it has a t-statistical value of 5.589 (t-statistics > 1.96) and a p-value of $0.000(\mathrm{p}<0.05)$, so that $\mathrm{H} 3$ can be accepted (not rejected), with the conclusion that there is a significant and positive influence between Financial Literacy on Financial Management Behavior. This result is in line with [3], [16]. [15] and [2] which state that financial literacy has influenced financial management behavior. This result becomes an important finding since Financial Literacy has been the most influential on financial management behavior. 


\section{CONCLUSION \& SUGGESTION}

\subsection{Conclusion}

This study takes a sample of 185 respondents who are the people living in Jakarta during COVID-19 pandemic. This research uses Structural Equation Model (SEM) through the Smart (PLS) Partial Least Square program. Based on the results of the study, it can be concluded that financial attitude has a significant influence on financial management behavior. Financial knowledge and financial literacy also have significant impact to the financial management behavior. In this case, financial literacy turns out to be the main determining factors of model as exposed in figure 2 . Something that is quite unique in circumstances, such as the COVID-19 pandemic.

\subsection{Suggestion}

With the results obtained with all the limitations, the suggestions that can be given to further researchers are to add the number of other variables, such as parental income, parental education, or other variables, namely Social Aid Program to help Indonesian people to recover from COVID-19 impact and to expand the number of respondents from all sectors of society. Therefore, many researchers can obtain more accurate result so that it can strengthen results of previous studies, especially the research conducted [18] which is only at the level of literature studies.

\section{REFERENCES}

[1] Ajzen, I. (1991). The theory of planned behavior. Organizational Behavior And Human Decision Processes, 50, 179-211. https://doi.org/10.4135/ $9781446249215 . n 22$

[2] Ameliawati, M., \& Setiyani, R. (2018). "The Influence of Financial Attitude, Financial Socialization, and Financial Experience to Financial Management Behavior with Financial Literacy as the Mediation Variable. In International Conference on Economics, Business and Economic Education 2018, KnE Social Sciences, 811-832. https://doi.org/10.18502/kss.v3i10. 3174

[3] Anggraeni, A. A., \& Tandika, D. (2019). Pengaruh Financial Literacy dan Financial Attitude terhadap Financial Management Behavior. Pengaruh Financial Literacy Dan Financial Attitude Terhadap Financial Management Behavior, 5(1), 85-92.

[4] Bapat, D. (2019). Exploring Antecedents to Financial Management Behavior for Young Adults. Journal of Financial Counseling and Planning, 30(1), 44-55. https://doi.org/10.1891/1052-3073.30.1.44

[5] Chin, W. W. (1998). The partial least squares approach to structural equation modelling. In Marcoulides G. A. (Ed.). Modern Methods for Business Research, 295(2), 295-336.

[6] Dharmmesta, B. S. (1998). Theory Of Planned Behaviour Dalam Penelitian Sikap, Niat dan Perilaku Konsumen. Kelola, 7(18), 85-103.

[7] Hair, J. F., Ringle, C. M., \& Sarstedt, M. (2011). PLS-SEM: Indeed a silver bullet. Journal of Marketing Theory and Practice, 19(2), 139-152. https://doi.org/ 10.2753/MTP1069-6679190202

[8] Henseler, J., Ringle, C. M., \& Sinkovics, R. R. (2009). The use of partial least squares path modeling in international marketing. Advances in International Marketing, 20 (January), 277-319. https://doi.org/10. 1108/S1474-7979(2009)0000020014

[9] Herdjiono, I., \& Damanik, L. A. (2016). Pengaruh Financial Atti Tude, Financial Knowledge, Parental Income Terhadap Financial Management Behavior. Manajemen Teori Dan Terapan, 226-241.

[10] Ida, \& Dwinta, C. Y. (2010). Pengaruh Locus of Control, Financial Knowledge, Income Terhadap Financial Management Behavior. Pengaruh Locus of Control, Financial Knowledge, Income Terhadap Financial Management Behavior, 12(3), 131-144

[11] Khairani, F., \& Alfarisi, M. F. (2019). Analisis Pengaruh Financial Attitude, Financial Knowledge, Pendidikan Orang Tua Dan Parental Income Terhadap Financial Management Behavior Pada Mahasiswa S1 Universitas Andalas. Jurnal Ilmiah Mahasiswa Ekonomi Manajemen, 4(1), 360-371. https://scholar.google.com/ citations?user=e-MLpBIAAAAJ\&hl=en

[12] Kholilah, N. Al, \& Iramani, R. (2013). Studi Financial Management Behavior Pada Masyarakat Surabaya. Journal of Business and Banking, 3(1), 69-80. https://doi.org/10.14414/jbb.v3i1.255

[13] Mien, N. T. N., \& Thao, T. P. (2015). Factors Affecting Personal Financial Management Behaviors: Evidence from Vietnam. Factors Affecting Personal Financial Management Behaviors: Evidence from Vietnam, 1-16. https://doi.org/10.1161/01.HYP. 0000200705.61571 .95

[14] Otoritas Jasa Keuangan. (2019). Siaran Pers Survei OJK 2019: Indeks Literasi Dan Inklusi Keuangan Meningkat. Sp 58/Dhms/Ojk/Xi/2019, 1. 
[15] Prihartono, M. R. D., \& Asandimitra, N. (2018). Analysis Factors Influencing Financial Management Behaviour. Analysis Factors Influencing Financial Management Behaviour, 8(8), 309-329. https://doi.org/ 10.6007/ijarbss/v8-i8/4471

[16] Putri, I. R., \& Tasman, A. (2019). Pengaruh Financial Literacy dan Income terhadap Personal Financial Management Behavior pada Generasi Millennial Kota Padang. Jurnal Kajian Manajemen Dan Wirausaha, 01(1), 151-160.

[17] Ramadhan, A. Y., \& Asandimitra, N. (2019). Determinants of Financial Management Behavior of Millennial Generation in Surabaya. Determinants of Financial Management Behavior of Millennial Generation in Surabaya, 6(2), 129. https://doi.org/ 10.24252/minds.v6i2.9506

[18] Solihat, A. \& Nugraha. (2020),How Behavioral Finance During Pandemic Covid-19? Business Innovation \& Entrpreneurship Journal 2 (2), 131-137.

[19] Wetzels, M., Odekerken-Schröder, G., \& Van Oppen, C. (2009). Using PLS path modeling for assessing hierarchical construct models: Guidelines and empirical illustration. MIS Quarterly: Management Information Systems, 33(1), 177-196. https://doi.org/ $10.2307 / 20650284$

[20] Widayati, I. (2012). Faktor- Faktor yang Mempengaruhi Literasi Financial Mahasiswa Fakultas Ekonomi dan Bisnis Universitas Brawijaya. Acta Crystallographica Section E: Structure Reports Online, l(1), 89-99. https://doi.org/10.1107/ S1600536809037635

[21] Yap, R. J. C., Komalasari, F., \& Hadiansah, I. (2016). The Effect of Financial Literacy and Attitude on Financial Management Behavior and Satisfaction. The Effect of Financial Literacy and Attitude on Financial Management Behavior and Satisfaction RICHARD, 23(3), 140-146.

\section{APPENDIX}

Below is a brief outline of the questionnaire that was circulated, namely in the four variables discussed in the empirical model in Figures 1 and 2.

\begin{tabular}{|l|l|l|}
\hline NO. & \multicolumn{1}{|c|}{$\begin{array}{c}\text { FINANCIAL } \\
\text { KNOWLEDGE } \\
\text { INDICATORS }\end{array}$} & SCALE 1-5 \\
\hline 1 & $\begin{array}{l}\text { I know basic financial } \\
\text { terms }\end{array}$ & \\
\hline 2 & $\begin{array}{l}\text { I know how to manage } \\
\text { finances }\end{array}$ & \\
\hline 3 & $\begin{array}{l}\text { I know about saving and } \\
\text { investing }\end{array}$ & \\
\hline 4 & $\begin{array}{l}\text { I know about financial } \\
\text { and insurance risks }\end{array}$ & \\
\hline 5 & $\begin{array}{l}\text { I know about credit or } \\
\text { debt }\end{array}$ \\
\hline
\end{tabular}

\begin{tabular}{|c|l|c|}
\hline NO. & \multicolumn{1}{|c|}{$\begin{array}{c}\text { FINANCIAL ATTITUDE } \\
\text { INDICATORS }\end{array}$} & SCALE 1-5 \\
\hline 1 & I can manage finances well & \\
\hline 2 & $\begin{array}{l}\text { I feel satisfied after shopping for } \\
\text { my needs }\end{array}$ & $\begin{array}{l}\text { I feel comfortable and safe when I } \\
\text { have money }\end{array}$ \\
\hline 4 & $\begin{array}{l}\text { I feel that my income is } \\
\text { insufficient }\end{array}$ & $\begin{array}{l}\text { I don't feel like spending my } \\
\text { money }\end{array}$ \\
\hline 5
\end{tabular}

\begin{tabular}{|c|l|l|}
\hline NO. & \multicolumn{1}{|c|}{$\begin{array}{c}\text { FINANCIAL LITERACY } \\
\text { INDICATORS }\end{array}$} & SCALE 1-5 \\
\hline 1 & $\begin{array}{l}\text { It is very important for me to } \\
\text { manage my personal finances }\end{array}$ & $\begin{array}{l}\text { In my opinion, knowledge of } \\
\text { finance is very important for } \\
\text { success and well-being both in the } \\
\text { present and in the future }\end{array}$ \\
\hline 3 & $\begin{array}{l}\text { I have sufficient knowledge about } \\
\text { credit or loans to avoid financial } \\
\text { doubts }\end{array}$ & \\
\hline 4 & $\begin{array}{l}\text { I act frugally in all aspects of my } \\
\text { finances, such as determining the } \\
\text { priority scale }\end{array}$ & \\
\hline 5 & $\begin{array}{l}\text { I think good financial management } \\
\text { can help with long and short-term } \\
\text { planning }\end{array}$ & \\
\hline
\end{tabular}

\begin{tabular}{|c|l|l|}
\hline NO. & $\begin{array}{l}\text { FINANCIAL MANAGEMENT } \\
\text { BEHAVOR INDICATORS }\end{array}$ & SCALE 1-5 \\
\hline 1 & $\begin{array}{l}\text { I compare the prices of goods } \\
\text { when shopping }\end{array}$ & \\
\hline 2 & I pay my bills on time & $\begin{array}{l}\text { I spend money according to the } \\
\text { budget that I have made }\end{array}$ \\
\hline 4 & $\begin{array}{l}\text { I started thinking about a plan to } \\
\text { invest }\end{array}$ & \\
\hline 5 & $\begin{array}{l}\text { I am leaving some of my money to } \\
\text { save }\end{array}$ & \\
\hline
\end{tabular}

